In the opinion of the Author stress history exerts its main influence via its modifications, often of a subtle nature, to the fabric of the clay soil. This argument applies equally to clays and sands, both of which exhibit an initial structural anisotropy; which is subsequently modified by the development of an induced anisotropy during deformation. An extra factor introduced by stress history may be the development of interparticle bonds including cementing in clay soil; the influence of these bonds on anisotropic response has been demonstrated by Mitchell $(1970,1972)$.

The Author agrees with the Writers that one must be cautious in generalizing the anisotropic response of clays and sands. However, despite the complications such as bond formation and cementation in certain clay soils, it appears there is a resemblance in the essentially granular mechanisms of deformation and failure in sands and clay soils.

\title{
REFERENCES
}

Duncan, J. M. \& Seed, H. B. (1966a). Anisotropy and stress reorientation in clays. Jnl Soil Mech. Fdns Div. Am. Soc. Civ. Engrs 92, SM5, 21-50.

Duncan, J. M. \& Seed, H. B. (1966b). Strength variation along failure surfaces in clay. Jnl Soil Mech. Fdns Div. Am. Soc. Civ. Engrs 92, SM6, 81-104.

Ingles, O. G. \& Lee, I. K. (1971). The influence of initial grain shape and pore anisotropy on strength of brittle soils. Géotechnique 21, 143-154.

Mitchell, R. J. (1970). On the yielding and mechanical strength of Leda clays. Can. Geotech. Jnl 3, 297-312.

Mitchell, R. J. (1972). Some deviations from isotropy in a lightly overconsolidated clay. Géotechnique 22, No. 3, 459-467.

Parry, R. H. G. (1972). Some properties of heavily overconsolidated Oxford clay at a site near Bedford. Géotechnique 22, No. 3, 485-507.

Skempton, A. W. \& Hutchinson, J. (1969). Stability of natural slopes and embankment foundation. State of art report, 7th Int. Conf. Soil Mech., Mexico. State of the art volume, 308-332.

\section{Lias clay: weathering processes and their effect on shear strength}

CHANDLER, R. J. (1972). Géotechnique 22, No. 3, 403-431.

\section{R. A. Nicholls, Nicholls Colton and Partners, Leicester}

The Author suggests that certain disturbances in the fabric of the Lias clay at Wothorpe are due to permafrost conditions, and the formation and subsequent melting of ice lenses. Given the hypothesis that permafrost conditions existed, the Writer believes that it is not necessary for ice lenses to have formed for disturbance to have occurred. The work of Williams (1968) has shown that when a zero isotherm penetrates a soil-water mass the larger pores fill with ice before the smaller. Everett (1961), Corte (1963) and Freden (1965) also showed that freezing and freezing-thawing cycles produced forces sufficient to displace individual particles. The lithorelicts can therefore be accounted for as volumes of clay, whose pore sizes were small enough to remain largely unfrozen, surrounded by clay altered by freezing and thawing. The lithorelicts would rotate as individual particles.

The presence of permafrost conditions might also account for the apparent discrepancy between the low water contents at Rockingham and the estimate of previous maximum overburden. Temperatures below freezing point in a soil mass produce large negative pore water pressures (Schofield, 1935). Washburn (1956) and Williams (1968) reported effects in permafrost areas which can be attributed to increased effective stress, i.e. shaley or flakey structures. 
A temperature of about $11^{\circ} \mathrm{C}$ below freezing point would produce an increase in effective stress of the same order as the assumed previous maximum overburden $(700 \mathrm{~m})$, and a temperature of $23^{\circ} \mathrm{C}$ below would produce an increase of twice the value. The freezing point at depth would depend on the overburden value. At temperatures of this order, the pores of $10^{-5} \mathrm{~mm}$ dia. or less will still remain free of ice. The low permeability mentioned in the footnote shows such small pore sizes are possible, and the low value is an indication that the production of ice lenses would not have been a general feature.

Corte, A. E. (1963). Vertical migration of particles in front of a freezing plane. Research Report 105, US Army Cold Regions Research and Engineering Laboratory.

Everett, D. H. (1961). The thermodynamics of frost damage to porous solids. Trans. Faraday Soc. 57, Part 9, 1541-1551.

Freden, S. (1965). Mechanism of frost heave and its relation to heat flow. Proc. 6th Int. Conf. Soil Mech., Montreal 1, 46-50.

Schofield, R. K. (1935). The pF of water in soil. Proc. 3rd Int. Congr. Soil Sci. 2, 37-48.

Washburn, A. L. (1956). Classification of patterned ground and a review of suggested origins. Bull. Geol. Soc. Am. 67, 823-866.

Williams, P. J. (1968). Properties and behaviour of freezing soils. Oslo: Norwegian Geotechnical Institute.

\section{R. J. Chandler}

I note with interest the Writer's suggestion that the brecciation of the Lias clay at Wothorpe is the result of freezing during the development of permafrost, rather than the consequence of the melting of ground ice.

However, the low water content of the Lias at Rockingham is more difficult to explain. If this results from freezing processes, then it is strange that the fabric of the Lias at Rockingham shows none of the brecciation that appears elsewhere as a result of freezing! It is my opinion that the low water content is more likely to be the consequence of diagenetic rather than consolidation processes.

\section{R. K. Taylor, University of Durham and D. A. Spears, University of Sheffield}

Dr Chandler's pertinent study of Lias clay weathering raises a number of questions which are relevant to other clay-shale weathering projects.

The limitation of carbonates as weathering indices is often a reflexion of the non-uniform distribution of these non-detrital or diagenetically altered minerals. The solubility of different carbonate species varies considerably and the equilibrium attained under leaching conditions is dependent on the throughput of water. Moreover, under certain environmental conditions carbonates will tend to concentrate during weathering. A current investigation of the Ampthill clay-shale implies that in a $50 \mathrm{~m}$ thick sequence calcite and quartz have a reciprocal relationship. Although Siever (1959) demonstrated in geochemical terms the possible incompatibility of the two minerals, from thin section observations, in the Ampthill sequence the relationship is governed purely by the original rate of deposition. Under a low rate of deposition in the bottom half of the sequence, fossils (now diagenetically recrystallized as calcite rhombs) accumulated; in the upper part of the succession the rate of deposition increased and the resulting rock was more silty (increase in quartz, decrease in fossil debris). Similarly, siderite, which is the common carbonate of coal measures argillaceous rocks, tends to be nonuniformly distributed and is therefore of limited value for monitoring weathering processes (Spears and Taylor, 1972).

The Writers agree with the Author's contention regarding oxidation of pyrite, which again, like other non-detrital minerals, tends to be non-uniformly distributed. Formation of secondary gypsum as a consequence of pyrite oxidation and reaction of the resulting $\mathrm{H}_{2} \mathrm{SO}_{4}$ with 
available carbonates can take place at depth and hence be greatly in advance of any nearsurface oxidation processes. This was demonstrated in the Yorkshire Main Colliery tip investigations (Spears et al., 1971). Most of the gypsum in the tip was derived from coal waste from underground and $\mathrm{X}$ ray studies confirmed that gypsum occurred with carbonates (ankerite and calcite) and kaolinite on the faces of the coal cleat. The carbonates post-date the jointing (cleating) of the coal, and are indicative of ground water flow at depth. The coal was the source of the subsequently oxidized pyrite.

Pyrite decomposes readily during weathering but monitoring the breakdown by means of the $\mathrm{Fe}_{2} \mathrm{O}_{3}: \mathrm{FeO}$ ratio could be misleading. Although pyrite $\left(\mathrm{FeS}_{2}\right)$ is a ferrous mineral the standard redox titration method does not determine the $\mathrm{Fe}^{2+}$ attributable to pyrite. Pyrite is included in colorimetrically determined $\mathrm{Fe}_{2} \mathrm{O}_{3}$ values, i.e. total iron minus $\mathrm{FeO}$. There are theoretical approaches for obtaining an $\mathrm{Fe}^{3+}$ figure which is independent of total iron, but the real problem in conventional analytical methods is to get pyrite into solution and still obtain a correct $\mathrm{FeO}$ value. Some of the variation in Dr Chandler's $\mathrm{Fe}_{2} \mathrm{O}_{3}: \mathrm{FeO}$ ratios is probably a function of pyrite content.

From the weathering scheme adopted (Table 1), chemical changes along fissures (zone II) are partly related to the availability (hence origin) of the discontinuities. In a weathering study of in situ coal measures shales and mudstones at a site near Rotherham, Yorkshire (Spears and Taylor, 1972), the 'lithorelicts in matrix' (三 to zone III) did not exceed $1.98 \mathrm{~m}$ in depth. For these older, more indurated rocks the depth would appear to be generally less than that for the Lias. It will be of interest to see if in the absence of too much climaticvegetation variation, an approximate age (induration) relationship with zone III depth of weathering is applicable to shale-type rocks in Britain.

\title{
REFERENCES
}

Siever, R. (1959). Petrology and geochemistry of silica cementation in some Pennsylvanian sandstones. Soc, Econ. Palaeont Mineralogy, Special Publication No. 7, 55 - 79.

Spears, D. A., Taylor, R. K., \& Till, R. (1971). A mineralogical investigation of a spoil heap at Yorkshire Main Colliery. Q. Jnl Engng Geol. 3, 239-252.

Spears, D. A. \& Taylor, R. K. (1972). The influence of weathering on the composition and engineering properties of in situ coal measures rocks. Int. Inl Rock Mech. Min. Sci. 9, 729-756.

\section{Prediction of undrained deformations and pore pressures in weak clay under two embankments}

\author{
RAYMOND, G. P. (1972). Géotechnique 22, No. 3, 381-431.
}

\section{G. J. W. King, Civil Engineering Department, Liverpool University}

The Author maintains that a transversely isotropic elastic model is more unlikely to predict smaller immediate settlements than an isotropic one. His opinion is influenced largely by the restriction he placed on the upper limit of the independent shear modulus $G_{\mathrm{u}}$ (Raymond, 1970) after considering the expression

$$
\sigma_{z}=\frac{P_{z}}{2 \pi} \frac{1}{\sqrt{ } \alpha-\sqrt{ } \beta}\left[\frac{1}{\left(r^{2}+\frac{z^{2}}{\alpha}\right)^{3 / 2}}-\frac{1}{\left(r^{2}+\frac{z^{2}}{\beta}\right)^{3 / 2}}\right]
$$

quoted by Barden (1963) for the vertical stress at a point $(r, z)$ in a semi-infinite transverselyisotropic elastic medium because of a point load $p$ on its surface. The reasoning in other papers (Hollingshcad and Raymond, 1971, 1972) has also been influenced by this restriction. 